Situs Jurnal : $\underline{\text { http://ejurnal.stiepancasetia.ac.id/index.php/jieb }}$

Jilid 4 Nomor 1 Maret 2018

Hal $047-057$

\title{
ANALISIS SUMBER DAN PENGGUNAAN MODAL KERJA PADA PT. PELAYARAN BINA BENUA SAMUDERA BANJARMASIN
}

\section{Nawan Samora*}

Abstract: The purpose of this study is (1) to analyze the source report and use of working capital at PT Pelayaran Bina Benua Samudera Banjarmasin during this time; and (2) to analyze the result of performance ratio of financial statement and company efficiency level in the use of working capital. This research is descriptive qualitative. The results showed that PT Pelayaran Bina Benua Samudra Banjarmasin is less efficient in the use of working capital. This can be seen from the source report and the use of working capital comparable with the financial performance report of PT Pelayaran Bina Benua Samudra Banjarmasin which recorded the minor value in 2015 and 2016, so that the presentation of financial statements into records for the company in the future more able to manage the source of working capital well.

Keywords: source analysis, use of working capital

Abstrak: Tujuan penelitian ini adalah untuk (1) menganalisis laporan sumber dan penggunaan modal kerja pada PT Pelayaran Bina Benua Samudera Banjarmasin selama ini terjadi; dan (2) menganalisis hasil rasio kinerja laporan keuangan dan tingkat efisiensi perusahaan dalam penggunaan modal kerjanya. Penelitian ini adalah deskriptif kualitatif. Hasil penelitian menunjukkan bahwa PT Pelayaran Bina Benua Samudra Banjarmasin kurang efisien dalam penggunaan modal kerjanya. Hal ini dapat dilihat dari laporan sumber dan penggunaan modal kerja yang dikomparasi dengan laporan kinerja keuangan PT Pelayaran Bina Benua Samudra Banjarmasin yang mencatatkan nilai minor pada tahun 2015 dan 2016, sehingga penyajian laporan keuangan menjadi catatan bagi perusahaan agar ke depannya lebih bisa mengelola sumber modal kerjanya dengan baik

Kata kunci : analisis sumber, penggunaan modal kerja

\section{Latar Belakang}

Selama kurun waktu dari tahun 2014 sampai 2016 laporan keuangan PT Pelayaran Bina Benua Samudera mengalami fluktuasi. Hal ini dapat dilihat narasi berikut: Pada tahun 2014 PT Pelayaran Bina Benua Samudera mencatatkan Laba Bersih Rp 7.836.529.662. Naik Signifikan pada tahun berikutnya yakni tahun 2015 sebesar Rp 18.601.286.754, sedangkan pada tahun 2016 mengalami penurunan dari tahun sebelumnya menjadi Rp 14.097.634.479. Akan tetapi, piutang perusahaan juga sangat besar nilainya. Hal ini mengakibatkan apabila kita membaca laporan keuangan tidak secara utuh akan muncul anggapan bahwa perusahaan ini tidak lancar modal kerja yang berputar didalamnya yang mengakibatkan hutang jangka panjang dan jangka pendeknya membengkak. Dengan angka yang relatif besar yang disajikan laporan keuangan perusahaan PT Pelayaran Bina Benua Samudera Banjarmasin menjadi tidak sesuai dengan realita yang ada di operasional perusahaan, karena selama ini perusahaan dalam menjalankan operasional hariannya di periode tertentu mengalami kesulitan dalam pembayaran biaya 
maupun hutang jangka pendeknya akan tetapi perusahaan juga di periode tertentu mengalami proses di mana uang kas perusahaan terlalu banyak mengendap di bank.

Dari uraian tersebut maka perlu analisis mendalam untuk mengukur modal kerja di perusahaan ini. Dengan teknik atau alat analisis sumber dana dan penggunaan dana, manajemen perusahaan pelayaran ini akan mengetahui bagaimana dana yang selama ini berputar di perusahaan digunakan atau dibelanjakan. Selain itu, diperoleh informasi mengenai sebabsebab terjadinya surplus atau defisit modal kerjanya selama periode tertentu, sehingga dapat dijadikan bahan pertimbangan manajemen perusahaan dalam pengambilan keputusan berkaitan dengan permodalan di kemudian hari. Mengingat pentingnya pengelolaan modal kerja dalam suatu perusahaan menjalankan kegiatan usahanya, maka hal tersebut mendasari penulis untuk mengkaji lebih jauh penggunaan modal kerja pada perusahaan PT Pelayaran Bina Benua Samudera Banjarmasin.

Berdasarkan pada latar bepakang yang telah dikemukakan, maka dapat dirumuskan apa yang menjadi tujuan penelitian ini adalah sebagai berikut ini:

1. Menganalisis laporan sumber dan penggunaan modal kerja pada PT Pelayaran Bina Benua Samudera Banjarmasin selama ini terjadi.

2. Menganalisis hasil rasio kinerja laporan keuangan dan tingkat efisiensi perusahaan dalam penggunaan modal kerjanya.

\section{Kajian Literatur}

Menurut Riyanto (2012:03) manajemen keuangan adalah keseluruhan aktivitas perusahaan yang berhubungan dengan usaha mendapatkan dana yang diperlukan dengan biaya yang minimal dan syarat syarat yang paling menguntungkan beserta usaha untuk menggunakan dana tersebut seefisien mungkin. Secara umum manajemen keuangan merupakan suatu proses dalam kegiatan keuangan perusahaan yang berhubungan dengan upaya untuk mendapatkan dana perusahaan serta meminimalkan biaya perusahaan dan juga upaya pengelolaan keuangan suatu badan usaha atau organisasi untuk dapat mencapai tujuan keuangan yang telah ditetapkan.

Manajemen keuangan dalam kegiatannya harus mengambil keputusan yang sering disebut dengan fungsi manajemen keuangan, yaitu: penggunaan dana (keputusan investasi), memperoleh dana (keputusan pendanaan), dan pembagian laba (kebijakan dividen). Tujuan manajemen keuangan telah terlihat dalam proses penilaian yang dilakukan oleh pasar uang. Tujuan utama manajemen keuangan adalah memaksimalkan kekayaaan pemegang saham. Tingkah laku pasar keuangan harus dipakai dalam menentapkan tujuantujuan perusahaan yang bersifat membela kepentingan pemegang saham. Yang dimaksud membela kepentingan pemegang saham atau memaksimumkan kemakmuran pemegang saham yaitu:

1. memaksimumkan nilai sekarang (present value) semua keuntungan di masa datang yang akan diterima oleh pemilik perusahaan; dan

2. lebih menekankan pada aliran hasil bukan sekedar laba bersih dalam pengertian akuntansi.

Kelebihan tujuan memaksimumkan nilai perusahaan/kemakmuran pemegang saham adalah secara konseptual jelas sebagai pedoman di dalam pengambilan keputusan yang memprtimbangkan faktor risiko. Dalam pencapaian tujuan tersebut, manajemen keuangan harus dapat menyeimbangkan kepentingan pemilik, kreditor, dan pihak lain yang berkaitan dengan perusahaan. Memaksimumkan kemakmuran pemegang saham/pemilik perusahaan tidak mengingkari adanya social objectives dan kewajiban sosial. Tanggung jawab sosial adalah satu aspek penting dari tujuan perusahaan, maksudnya:

1. keberhasilan memaksimumkan nilai perusahaan akan memberikan sumbangan yang berarti kepada lingkungan sosial secara keseluruhan; 
2. pengaruh (dampak) lingkungan eksternal seperti polusi, keselamatan kerja, keamanan produk juga harus diperhitungkan;

3. kepekaan terhadap faktor eksternal merupakan salah satu syarat penting agar perusahaan tetap dapat mempertahankan kelangsungan hidup perusahaan; dan

4. perusahaan harus dapat memaksimumkan kemakmuran pemegang saham dalam kendala legal dan sosial dan bertanggungjawab terhadap perubahan lingkungan.

Manajemen keuangan adalah manajemen atas fungsifungsi keuangan. Mengenai fungsi keuangan ialah kegiatan utama dalam mempertanggungjawabkan bidang tertentu dalam menggunakan dana dan menempatkan dana. Manajemen dalam bisnis perusahaan terdiri dari beberapa individu yang dikategorikan dalam tiga kelompok yaitu sebagai berikut:

1. kelompok manajemen tingkat pelaksana (operational menegement), yang terdiri dari para suvervisor;

2. kelompok manajemen menengah meliputi kepada departement, manajer devisi, dan manger cabang.

3. manajemen eksekutif atau biasa disebut manajemen penanggung jawab akan fungsi pemasaran, pembelanjaan, produksi, pembiayaan, dan akutansi.

Manajemen keuangan tidak hanya pada pencatatan akuntansi saja. Manajemen keuangan merupakan bagian yang sangat penting dan tidak dapat dianggap sepele. Pada praktiknya manajemen keuangan meruakan aktivitas dan hadir untuk menyehatkan keuangan perusahaan atau organisasi. Prinsipprinsip manajemen keuangan adalah sebagai berikut ini.

1. Consistency (konsistensi), adalah prinsip yang mana sistem dan kebijakan keuangan perusahaan sesuai dengan apa yang direncanakan, tidak berubah dari setiap periode, tetapi yang perlu ditekankan bahwa sistem keuangan bukan berarti tidak dapat dilakukan penyesuaian ketika terdapat perubahan signifikan dalam perusahaan. Pendekatan keuangan yang tidak konsisten menjadi tanda bahwa ada manipulasi pada pengelolaan keuangan perusahaan.

2. Accountability (akuntabilitas), adalah suatu kewajiban hukum dan juga moral, yang mana melekat untuk setiap individu, kelompok ataupun perusahaan dalam memberi penjelasan bagaimana dana ataupun kewenangan yang telah diberikan oleh pihak ketiga dipergunakan. Setiap pihak harus memberi penjelasan mengenai penggunaan sumber daya dan apa yang telah dicapai suatu bentuk pertanggungjawaban kepada yang berkepentingan, agar semua tahu bagaimana kewenangan dan dana yang dimiliki itu dipergunakan.

3. Transparancy (transparansi), adalah prinsip yang mana setiap kegiatan manajemen harus terbuka baik dalam memberikan informasi tentang rencana dan segala aktivitas bagi yang berkepentingan, termasuk laporan keuangan yang wajar, lengkap, tepat waktu dan akurat yang dapat diakses dengan mudah oleh yang berkepentingan, jika tidak transparan maka akan berdampak suatu penyelewengan kegiatan.

4. Viability (kelangsungan hidup) adalah prinsip yang mana menekankan pada kesehatan keuangan perusahaan terjaga, semua pengeluaran operasional ataupun ditingkat yang strategi harus disesuaikan dengan dana yang ada, kelangsungan hidup entitas merupakan ukuran suatu tingkat keamanan serta keberlanjutan keuangan perusahaan. Manajemen keuangan harus menyusun rencana keuangan di mana menunjukkan bagaimana suatu perusahaan bisa menjalankan rencana strategisnya guna memenuhi kebutuhan keuangan.

5. Integrity (integritas) adalah setiap individu wajib mempunyai tingkat integritas yang mempuni dalam menjalankan kegiatan operasional. Tidak hanya itu, pencacatan dan laporan keuangan harus terjaga integritasnya dengan kelengkapan dan tingkat keakuratan suatu pencatatan keuangan. 
6. Stewardship (pengelolaan) adalah prinsip dimana dapat mengelola dengan baik dana yang telah didapatkan dan memberikan jaminan akan dana yang diperoleh tersebut untuk direalisasikan tujuan yang telah ditetapkan, dalam praktiknya dilakukan dengan hatihati dengan membuat perencanaan strategis, mengidentifikasi risiko keuangan yang ada serta menyusun dan membuat sistem pengendalian keuangan yang sesuai.

7. Accounting standards (standar akuntansi) adalah sistem akuntansi keuangan harus sesuai dengan prinsipprinsip dan standar aturan akuntansi yang telah berlaku dengan tujuan laporan keuangan yang dihasilkan dapat dengan mudah dipahami dan dimengerti dari semua pihak yang berkepentingan.

Menurut Ambarwati (2013:112) modal kerja adalah modal yang seharusnya tetap ada dalam perusahaan sehingga operasional perusahaan menjadi lebih lancar serta tujuan akhir perusahaan untuk menghasilkan laba akan tercapai. Waktu tersedianya modal kerja akan tergantung pada macam tingkat likuiditas dari unsur unsur aktiva lancar misalnya kas, piutang dan persediaan. Kasmir (2012: 250) menyatakan bahwa modal kerja merupakan modal yang digunakan untuk melakukan kegiatan operasi perusahaan. Modal kerja diartikan sebagai investasi yang ditanamkan dalam aktiva lancar atau aktiva jangka pendek seperti kas, bank, suratsurat berharga, piutang, dan persediaan. Pada umumnya pengertian modal kerja adalah dana yang diperlukan dalam operasional perusahaan seharihari. Misalnya, uang pembayaran gaji karyawan, pembayaran hutang, pembelian barang dan lainnya. Modal kerja ini terdiri dari dua elemen dasar yaitu aktiva lancar dan kewajiban lancar. Kedua hal ini menentukan bagaimana kegiatan operasional perusahaan, karena itu diperlukan pengelolaan yang baik dalam menggunakan manajemen modal kerjanya.

Menurut Munawir (2013:14) ada tiga konsep modal kerja yang umum digunakaan, yaitu sebagai berikut ini.

1. Konsep kuantitatif. Konsep ini menitikberatkan kepada kuantum yang diperlakukan untuk mencukupi kebutuhan perusahaan dalam membiayai operasinya yang bersifat rutin atau menunjukan jumlah dana (fund) yang tersedia untuk tujuan operasi jangka penpek. Dalam konsep ini menganggap bahwa modal kerja adalah jumlah aktiva lancar (gross working capital).

2. Konsep kualitatif. Konsep ini menitikberatkan pada kualitas modal kerja. Dalam konsep ini pengertian modal kerja adalah kelebihan aktiva lancar terhadap hutang jangka pendek (net working capital), yaitu jumlah aktiva lancar yang berasal dari pinjaman jangka panjang maupun para pemilik perusahaan.

3. Konsep fungsional. Konsep ini menitikberatkan fungsi dari dana yang dimiliki dalam rangka menghasilkan pendapatan (laba) dari usaha pokok perusahaan.

Modal kerja mampu membiayai pengeluaran atau operasi perusahaan seharihari. Dengan modal kerja yang cukup akan membuat perusahaan beroperasi secara ekonomis dan efesien serta tidak mengalami kesulitan keuangan. Manfaat modal kerja menurut Munawir (2013: 116) adalah:

1. melindungi perusahaan terhadap krisis modal kerja karena turunnya nilai dari aktiva lancar;

2. memungkinkan untuk dapat membayar semua kewajibankewajiban tepat pada waktunya;

3. memungkinkan untuk memiliki persediaan dalam jumlah yang cukup untuk melayani para konsumen;

4. memungkinkan bagi perusahaan untuk memberikan syarat kredit yang lebih menguntungkan kepada para langganannya; dan

5. memungkinkan bagi perusaahan untuk dapat beroperasi dengan lebih efesien karena tidak ada kesulitan untuk memperoleh barang ataupun jasa yang dibutuhkan. 
ini.

Pada umumnya sumber modal kerja suatu perusahaan dapat berasal dari sebagai berikut

1. Hasil operasi perusahaan, adalah jumlah net income yang nampak dalam laporan perhitungan rugi laba ditambah dengan depresiasi dan amortisasi. Jumlah ini menunjukkan jumlah modal kerja yang berasal dari hasil operasi perusahaan.

2. Keuntungan dari penjualan suratsurat berharga (investasi jangka pendek). Surat berharga yang dimiliki perusahaan untuk jangka pendek adalah salah satu elemen aktiva lancar yang segera dapat dijual dan akan menimbulkan keuntungan bagi perusahaan. Dengan adanya penjualan surat berharga ini menyebabkan terjadinya perubahan dalam unsur modal kerja yaitu dari bentuk surat berharga berubah menjadi uang kas.

3. Penjualan aktiva tidak lancar. Sumber lain yang dapat menambah modal kerja adalah hasil apenjualan aktiva tetap, investasi jangka panjang dan aktiva tidak lancar lainnya yang tidak diperlukan lagi oleh perusahaan. Perubahan dari aktiva ini menjadi kas atau piutang akan menyebabkan bertambahnya modal kerja sebesar hasil penjualan tersebut.

4. Penjualan saham atau obligasi Untuk menambah dana atau modal kerja yang dibutuhkan, perusahaan dapat pula mengadakan emisi saham baru atau meminta kepada para pemilik perusahaan untuk menambah modalnya. Di samping itu, perusahaan dapat juga mengeluarkan obligasi atau bentuk hutang jangka panjang untuk modal kerja lainnya.

Penggunaan modal kerja menurut Kasmir (2012:258) biasa dilakukan perusahaan untuk sebagai berikut ini.

1. Pengeluaran untuk gaji, upah dan biaya operasi perusahaan lainnya. Maksudnya dari pengeluaran untuk gaji, upah dan biaya operasi perusahaan lainya, perusahaan mengeluarkan sejumlah uang untuk membayar gaji dan biaya operasional perusahaan lainnya yang digunakaan untuk menunjang penjualan.

2. Pengeluaran untuk membeli bahan baku atau barang dagangan. Maksud pengeluaran untuk membeli bahan baku atau barang dagang adalah pada sejumlah bahan baku yang dibeli yang akan digunakaan untuk proses produksi dan pembelian barang dagang untuk di jual kembali.

3. Menutupi kerugian akibat penjualan surat berharga. Maksud menutupi kerugian akibat penjualan surat berharga adalah pada saat perusahaan menjual suratsurat berharga, namun mengalami kerugian. Hal ini akan mengurangi modal kerja dan segera ditutupi.

4. Pembentukan dana. Pembentukan dana merupakan pemisahan aktiva lancar untuk tujuan tertentu dalam jangka panjang, misalnya pembentukan dana pensiun, dana ekspansi, atau dana pelunasan obligasi. Pembentukan dana ini akan mengubah bentuk aktiva dari aktiva lancar menjadi aktiva tetap.

5. Pembelian aktiva tetap (tanah, bangunan, kendaraan, dan mesin). Pembelian aktiva tetap atau investasi jangka panjang seperti pembelian tanah, bangunan, kendaraan dan mesin. Pembelian ini akan mengakibatkan berkurangnya aktiva lancar dan timbulnya utang lancar.

Industri jasa pelayaran merupakan usaha industri jasa transportasi laut atau shipping industry yang memberikan manfaat yang sangat besar bagi perpindahan suatu barang, baik memberikan manfaat secara place utility yaitu barang yang disatu tempat kurang bermanfaat dipindahkan ke tempat yang dari satu tempat yang saat tertentu sudah diproduksi dan berlebihan dipindahkan ke tempat yang pada waktu yang sama belum diproduksi. Jenisjenis jasa pelayaran yang saat ini berlaku terbagi atas sebagai berikut ini.

1. Berdasarkan bidang kegiatannya. Dilihat dari bidang kegiatannya,bidang kegiatan pelayaran terbagi menjadi dua jenis yakni pelayaran niaga dan pelayaran non niaga. Pelayaran niaga yaitu usaha pengangkutan barang (khususnya barang dagang maupun barang setengah jadi) 
atau penumpang melalui laut baik yang dilakukan antar pelabuhan pelabuhan dalam wilayah sendiri maupun antar negara, sedangkan pelayaran non niaga adalah kegiatan pelayaran yang bertujuan bukan untuk kegiatan perdagangan melainkan pelayaran angkatan perang, dinas pos, dinas perambuan, penjaga pantai dan sebagainya.

2. Berdasarkan trayek yang dilayari. Kegiatan pelayaran dilihat dari trayek yang dilayarinya terbagi atas pelayaran nasional dan kegiatan pelayaran internasional. Dalam kegiatan pelayaran nasional, kegiatan pelayaran yang berlangsung dalam batas batas wilayah territorial suatu negara atau sering disebut pelayaran interinsular. Sementara itu, dalam pelayaran internasional kegiatan pelayaran itu berlangsung dalam perairan internasional yang menghubungkan dua negara atau lebih, pelayaran internasional dalam dunia shipping dikenal dengan sebutan pelayaran samudera. Pada pelayaran internasional timbul masalah hubungan hukum internasional dan timbullah berbagai konvensi internasional yang mengatur aspek aspek pelayaran, baik yang berkaitan dengan masalah teknis, hukum positif, maupun yang berkenaan dengan penyelenggaraan atau perusahaan pelayaran.

\section{Metode Penelitian}

Penulis menggunakan studi deskriptif kualitatif. Jenis ini adalah di mana data yang berkaitan dengan masalah penelitian yang berasal dari bukubuku, modul perusahaan serta sumber lainnya. Dalam penelitian ini terdapat uapaya mendeskripsikan, mencatat dan meniterpretasikan kondisi sekarang kemudian melakukan evaluasi yang berguna sebagai masukan terhadap pengambilan kebijakan perusahaan.

Jenis data dalam penelitian ini terdiri atas data kuantitatif dan data kualitatif. Data kuantitatif adalah data yang dinyatakan dalam bentuk angkaangka yang berumber dari data perusahaan berupa transaksitransaksi, laporan keuangan yang terdiri dari laporan catatancatatan transaksi penjualan dan pembelian di perusahaan. Data kualitatif adalah data yang dapat dikategorikan tetapi tidak dapat dikuantitatifkan (bukan bentuk satuan angka), melainkan dalam bentuk penjelasan yang menggambarkan proses keadaan peristiwa tertentu yang bersumber dari obyek penelitian yang diperoleh melalui wawancara dan tanya jawab dengan pimpinan dan karyawan terkait dengan obyek penelitian.

Sumber data dalam penelitian ini terdiri atas data primer dan data sekunder. Data primer adalah data yang didapat langsung dari wawancara berupa keterangan yang berhubungan dengan penggunaan modal kerja pada laporan keuangan PT Pelayaran Bina Benua Samudera. Data sekunder merupakan sumber data penelitian yang diperoleh secara tidak langsung berupa catatan dokumen resmi perusahaan yang bertujuan sebagai pendukung data primer.

Teknik pengumpulan data dalam penelitian ini adalah observasi, wawancara, dan dokumentasi. Observasi dilakukan dengan pengamatan terhadap kegiatan untuk mendapatkan bukti yang valid karena dengan cara mengamati secara tidak langsung objek akan diteliti. Wawancara) dilakukan dengan tanya jawab secara langsung dengan pihakpihak yang berkaitan dengan objek penelitian, seperti wawancara dengan manajer bagian keuangan. Penelitian yang dilakukan dengan cara mencari data mengenai masalah yang dibahas dan yang berhubungan dengan dokumen, catatan, serta laporan yang telah terjadi yang sesuai dengan masalah.

Penulis menggunakan studi deskriptif. Jenis ini adalah dimana data yang berkaitan dengan masalah penelitian yang berasal dari bukubuku, modul perusahaan serta sumber lainnya yang mendukung penelitian skripsi ini. Dalam penelitian ini terdapat upaya mendeskripsikan, mencatat dan menginterpretasikan kondisi sekarang kemudian melakukan evaluasi.

\section{Hasil Penelitian dan Pembahasan}

Laporan keuangan PT Pelayaran Bina Benua Samudra disusun setiap tiga bulan sekali yakni pada bulan Maret, Juni, September dan Desember untuk penutupan akhir periode 
akuntansi. Berikut ini disajikan laporan keuangan periode 2014, 2015 dan 2016 dalam bentuk perbandingan pada Tabel 1 dan Tabel 2 serta laporan sumber dan penggunaan modal kerja yang selama ini dilakukan pada Tabel 3.

Tabel 1. Laba Rugi Periode 2014, 2015 dan 2016

\begin{tabular}{lrrr}
\hline \multicolumn{1}{c}{ Keterangan } & \multicolumn{1}{c}{2016} & \multicolumn{1}{c}{2015} & \multicolumn{1}{c}{2014} \\
\hline Pendapatan & $66,293,226,550.00$ & $85,487,096,290.00$ & $79,301,986,893.00$ \\
\hline Beban langsung & $(41,268,621,489.64)$ & $(52,433,355,768.00)$ & $(60,715,969,128.00)$ \\
\hline Laba (rugi) kotor & $\mathbf{2 5 , 0 2 4 , 6 0 5 , 0 6 0 . 3 6}$ & $\mathbf{3 3 , 0 5 3 , 7 4 0 , 5 2 2 . 0 0}$ & $\mathbf{1 8 , 5 8 6 , 0 1 7 , 7 6 5 . 0 0}$ \\
\hline Beban usaha : & & & \\
\hline Beban umum dan administrasi & $2,288,405,900.00$ & $2,516,085,177.00$ & $1,225,141,083.00$ \\
\hline Jumlah beban usaha & $2,288,405,900.00$ & $2,516,085,177.00$ & $1,225,141,083.00$ \\
\hline Laba (rugi) usaha & $\mathbf{2 2 , 7 3 6 , 1 9 9 , 1 6 0 . 3 6}$ & $\mathbf{3 0 , 5 3 7 , 6 5 5 , 3 4 5 . 0 0}$ & $\mathbf{1 7 , 3 6 0 , 8 7 6 , 6 8 2 . 0 0}$ \\
\hline Pendapatan (beban) lainlain : & $2,863,095,665.71$ & $3,001,305,724.00$ & $469,000,708.00$ \\
\hline Pendapatan lainlain & $(11,032,189,645.29)$ & $(14,358,964,863.00)$ & $(9,456,508,704.00)$ \\
\hline Beban lainlain & & & \\
\hline Jumlah pendapatan (beban) & $(8,169,093,979.58)$ & $(11,357,659,139.00)$ & $(8,987,507,996.00)$ \\
lainlain & $\mathbf{1 4 , 5 6 7 , 1 0 5 , 1 8 0 . 7 8}$ & $\mathbf{1 9 , 1 7 9 , 9 9 6 , 2 0 6 . 0 0}$ & $\mathbf{8 , 3 7 3 , 3 6 8 , 6 8 6 . 0 0}$ \\
\hline Laba bersih sebelum pajak & $(469,470,700.80)$ & $(578,709,452.00)$ & $(536,839,024.00)$ \\
\hline Pajak penghasilan - final & $\mathbf{1 4 , 0 9 7 , 6 3 4 , 4 7 9 . 9 8}$ & $\mathbf{1 8 , 6 0 1 , 2 8 6 , 7 5 4 . 0 0}$ & $\mathbf{7 , 8 3 6 , 5 2 9 , 6 6 2 . 0 0}$ \\
\hline Laba bersih & & &
\end{tabular}

\section{Tabel 2. Neraca Periode 2014, 2015 dan 2016}

\begin{tabular}{|c|c|c|c|}
\hline Keterangan & 2016 & 2015 & 2014 \\
\hline \multicolumn{4}{|l|}{ Aset } \\
\hline \multicolumn{4}{|l|}{ Aset lancar } \\
\hline Kas dan setara kas & $10,946,042,623$ & $4,046,796,024$ & $6,905,105,949$ \\
\hline Piutang usaha & $127,983,314,255$ & $89,460,181,104$ & $36,497,169,568$ \\
\hline Piutang lainlain & $1,848,899,292$ & $1,611,049,292$ & $5,597,620,195$ \\
\hline Persediaan & $896,357,765$ & $938,359,347$ & $3,262,894,347$ \\
\hline Uang muka & $48,906,540,936$ & $13,702,963,655$ & $20,018,056,968$ \\
\hline Jumlah aset lancer & $190,581,154,871$ & $109,759,349,422$ & $72,280,847,027$ \\
\hline \multicolumn{4}{|l|}{ Aset tidak lancar } \\
\hline Aset tetap (setelah dikurangi akm penyusutan) & $111,978,337,571$ & $121,390,327,184$ & $125,406,688,455$ \\
\hline Aset lainlain & 0 & & $294,639,667$ \\
\hline Jumlah aset tidak lancar & $111,978,337,571$ & $121,390,327,184$ & $125,701,328,122$ \\
\hline Jumlah aset & $302,559,492,443$ & $231,149,676,606$ & 197,982,175,149 \\
\hline \multicolumn{4}{|l|}{ Kewajiban dan ekuitas } \\
\hline \multicolumn{4}{|l|}{ Kewajiban lancar } \\
\hline Utang usaha & $51,301,055,514$ & $24,964,905,353$ & $30,773,965,909$ \\
\hline Utang bank & $182,210,490$ & $15,000,000,000$ & $15,000,000,000$ \\
\hline Utang pajak & $13,545,000$ & $465,374,352$ & $811,846,480$ \\
\hline Biaya yang masih harus dibayar & & $8,865,000$ & $3,072,000$ \\
\hline Utang bank jatuh tempo kurang 1 tahun & $25,000,000,000$ & $30,307,227,484$ & $17,896,614,521$ \\
\hline Utang pembiayaan & & & $1,220,988,000$ \\
\hline Jumlah kewajiban lancar & $76,496,811,004$ & $70,746,372,189$ & $65,706,486,910$ \\
\hline \multicolumn{4}{|l|}{ Hutang jangka panjang } \\
\hline Utang bank jangka panjang & $112,283,542,263$ & $65,225,451,995$ & $44,934,365,479$ \\
\hline \multicolumn{4}{|l|}{ Utang pembiayaan } \\
\hline Jumlah kewajiban tidak lancer & $112,283,542,263$ & $65,225,451,995$ & $44,934,365,479$ \\
\hline \multicolumn{4}{|l|}{ Ekuitas } \\
\hline Modal saham & $4,250,000,000$ & $4,250,000,000$ & $4,250,000,000$ \\
\hline Saldo laba & $109,529,139,176$ & $90,927,852,422$ & $83,091,322,760$ \\
\hline Jumlah ekuitas pemegang saham & $113,779,139,176$ & $95,177,852,422$ & $87,341,322,760$ \\
\hline Jumlah kewajiban dan ekiutas & $302,559,492,443$ & $231,149,676,606$ & 197,982,175,149 \\
\hline
\end{tabular}


Tabel 3. Laporan Sumber dan Penggunaan Modal Kerja yang Selama Ini Dilakukan PT. Pelayaran Bina Benua Samudra.

\begin{tabular}{|c|c|c|c|c|}
\hline Keterangan & 2016 & 2015 & Naik & Turun \\
\hline \multicolumn{5}{|l|}{ Aset } \\
\hline \multicolumn{5}{|l|}{ Aset lancar } \\
\hline Kas dan setara kas & $10,946,042,623$ & $4,046,796,024$ & $6,899,246,599$ & \\
\hline Piutang usaha & $127,983,314,255$ & $89,460,181,104$ & $38,523,133,151$ & \\
\hline Piutang lainlain & $1,848,899,292$ & $1,611,049,292$ & $237,850,000$ & \\
\hline Persediaan & $896,357,765$ & $938,359,347$ & & $42,001,582$ \\
\hline Uang muka & $48,906,540,936$ & $13,702,963,655$ & $35,203,577,281$ & \\
\hline Jumlah aset lancar & $190,581,154,871$ & $109,759,349,422$ & & \\
\hline \multicolumn{5}{|l|}{ Aset tidak lancar } \\
\hline Aset tetap & $235,537,293,082$ & $235,537,293,082$ & & \\
\hline $\begin{array}{l}\text { Akumulasi } \\
\text { penyusutan }\end{array}$ & $123,558,955,511$ & $114,146,965,898$ & & $9,411,989,613$ \\
\hline Nilai buku & $111,978,337,571$ & $121,390,327,184$ & & \\
\hline Aset lainlain & 0 & & & \\
\hline $\begin{array}{l}\text { Jumlah aset tidak } \\
\text { lancar }\end{array}$ & $111,978,337,571$ & $121,390,327,184$ & & \\
\hline Jumlah aset & $302,559,492,443$ & $231,149,676,606$ & & \\
\hline $\begin{array}{ll}\begin{array}{l}\text { Kewajiban } \\
\text { ekuitas }\end{array} & \text { dan } \\
\end{array}$ & & & & \\
\hline \multicolumn{5}{|l|}{ Kewajiban lancar } \\
\hline Utang usaha & $51,301,055,514$ & $24,964,905,353$ & & $26,336,150,161$ \\
\hline Utang bank & $182,210,490$ & $15,000,000,000$ & $14,817,789,510$ & \\
\hline Utang pajak & $13,545,000$ & $465,374,352$ & $451,829,352$ & \\
\hline $\begin{array}{l}\text { Biaya yang masih } \\
\text { harus dibayar }\end{array}$ & & $8,865,000$ & $8,865,000$ & \\
\hline $\begin{array}{l}\text { Utang bank jatuh } \\
\text { tempo kurang } 1 \text { tahun }\end{array}$ & $25,000,000,000$ & $30,307,227,484$ & $5,307,227,484$ & \\
\hline \multicolumn{5}{|l|}{ Utang pembiayaan } \\
\hline $\begin{array}{l}\text { Jumlah kewajiban } \\
\text { lancar }\end{array}$ & $76,496,811,004$ & $70,746,372,189$ & & \\
\hline \multicolumn{5}{|l|}{$\begin{array}{l}\text { Kewajiban jangka } \\
\text { panjang }\end{array}$} \\
\hline $\begin{array}{l}\text { Utang bank jangka } \\
\text { panjang }\end{array}$ & $112,283,542,263$ & $65,225,451,995$ & & $47,058,090,268$ \\
\hline \multicolumn{5}{|l|}{ Utang pembiayaan } \\
\hline $\begin{array}{l}\text { Jumlah kewajiban } \\
\text { tidak lancer }\end{array}$ & $112,283,542,263$ & $65,225,451,995$ & & \\
\hline \multicolumn{5}{|l|}{ Ekuitas } \\
\hline Modal saham & $4,250,000,000$ & $4,250,000,000$ & & \\
\hline Saldo laba & $109,529,139,176$ & $90,927,852,422$ & & \\
\hline $\begin{array}{l}\text { Jumlah ekuitas } \\
\text { pemegang saham }\end{array}$ & $113,779,139,176$ & $95,177,852,422$ & & $18,601,286,754$ \\
\hline $\begin{array}{l}\text { Jumlah kewajiban } \\
\text { dan ekuitas }\end{array}$ & $302,559,492,443$ & 231,149,676,606 & & \\
\hline Jumlah & & & $101,449,518,378$ & $101,449,518,378$ \\
\hline
\end{tabular}


Tabel 4. Hasil Rasio Kinerja Laporan Keuangan dan Tingkat Efisiensi Perusahaan dalam Penggunaan Modal Kerjanya

\begin{tabular}{|c|c|c|c|}
\hline Keterangan & Jumlah & Keterangan & Jumlah \\
\hline Keuntungan neto & $14,097,634,480$ & Bertambahnya kas & $6,899,246,599$ \\
\hline Berkurangnya persediaan & $42,001,582$ & $\begin{array}{l}\text { Bertambahnya piutang } \\
\text { usaha }\end{array}$ & $38,523,133,151$ \\
\hline $\begin{array}{l}\text { Bertambahny akun depresiasi } \\
\text { asset }\end{array}$ & $9,411,989,613$ & $\begin{array}{l}\text { Bertambahnya piutang } \\
\text { lain lain }\end{array}$ & $237,850,000$ \\
\hline Bertambahnya hutang usaha & $26,336,150,161$ & $\begin{array}{l}\text { Bertambahnya uang muka } \\
\text { aset }\end{array}$ & $35,203,577,281$ \\
\hline Bertambahnya hutang bank ki & $47,058,090,268$ & $\begin{array}{l}\text { Berkurangnya hutang } \\
\text { bank KMK }\end{array}$ & $20,125,016,994$ \\
\hline \multirow[t]{3}{*}{ Bertambahnya modal } & $18,601,286,754$ & $\begin{array}{l}\text { Berkurangnya hutang } \\
\text { pajak }\end{array}$ & $451,829,352$ \\
\hline & & $\begin{array}{l}\text { Berkurangnya hutang lain } \\
\text { lain }\end{array}$ & $8,865,000$ \\
\hline & & $\begin{array}{l}\text { Bertambahnya laba } \\
\text { ditahan }\end{array}$ & $14,097,634,480$ \\
\hline Sumber modal kerja & $115,547,152,858$ & Penggunaan modal kerja & $115,547,152,858$ \\
\hline
\end{tabular}

Dari Tabel 3, diketahui sumber modal kerja pada PT Pelayaran Bina Benua Samudera Banjarmasin pada tahun 2016 sebagai berikut ini.

1. Laba tahun 2015 yang ditahan Rp 18.601.286.754.

2. Penggunaan persediaan Rp 42.001.582.

3. Penerimaan hutang usaha dan afiliasi Rp 26.336.150.161.

4. Penambahan kredit investasi dari Bank BNI Rp 47.058.090.267.

5. Laba bersih tahun $2016 \mathrm{Rp}$ 14.097.634.479.

Sementara itu penggunaanya adalah sebagai berikut ini.

1. Menambah saldo kas dan bank Rp 6.899.246.599.

2. Memberikan piutang usaha dan afiliasi Rp 38.523.133.151.

3. Membeli aset (tongkang dan tugboat) dengan cara mengangsur Rp 35.203.577.280 sebagai uang muka terlebih dahulu.

4. Membayar hutang kredit modal kerja senilai Rp 20.125.016.994, pada Bank BNI.

5. Membayar hutang pajak senilai Rp 451.829.352.

Berdasarkan pada hasil penelitian yang telah dikemukakan, maka dapat disampaikan serangkaian implikasi penelitian ini adalah sebagai berikut ini.

1. Bertambahnya nilai piutang usaha membuat dilema buat perusahaan hal ini karena besarnya nilai piutang usaha mempengaruhi nilai cash rasio perusahaan.

2. Membeli asset untuk penambahan kapal, penulis menilai perusahaan telah mempersiapkan ekspansinya akan tetapi di tengah lesunya ekonomi nasional perusahaan seharusnya tidak terlalu besar dalam pengalokasian pembelian aset.

3. Dengan cash rasio yang secara perhitungan tidak menunjukkan kinerja yang memuaskan perusahaan telah berani menghapus secara keseluruhan KMK nya. 


\section{Kesimpulan}

Berdasarkan hasil penelitian dan pembahasan yang telah dijabarkan sebelumnya maka dapat disimpulkan penelitian ini sebagai berikut ini.

1. Berdasarkan laporan sumber dan penggunaan modal kerja perusahaan, penulis menilai adanya salah pengunaan modal kerja. Kebijakan perusahaan dalam pengeluaran biaya yang sifatnya tidak urgent dan pembelian asset yang tidak produktif cenderung mengorbankan pembayaran hutang lancar yang sudah jatuh tempo.

2. Pada analisis laporan keuangan secara keseluruhan menunjukan ketidakefisienan perusahaan dalam menggunakan modal kerjanya dapat dilihat dari rasio likuiditasnya yang mencatatkan nilai rasio yang jauh dibawah dengan perusahaan terkait dan juga rasio rasio yang lain.

Dalam penelitian ini dapat diberikan masukan dan saran bagi perusahaan, yaitu sebagai berikut ini.

1. PT Pelayaran Bina Benua Samudera pada tahun 2014 berhasil melakukan pengangkutan kayu logs sebanyak $254.336,89 \mathrm{~m}^{3}$ dengan estimasi pendapatan Rp 79.301.986.893, sedangkan pada tahun 2016 perusahaan hanya mampu melakukan pengangkutan kayu logs sebanyak $244.734,87 \mathrm{~m}^{3}$ dengan estimasi pendapatan yang hanya sebesar $\mathrm{Rp}$ 66.293.226.550. Kesimpulannya selama dua periode berjalan perusahaan tidak pernah melakukan penyesuaian tarif yang ini mengakibatkan perusahaan kurang leluasa dalam menentukan laba bersih yang ingin dicapai di kemudian hari. Dengan pertimbangan inflasi dan kenaikan UMR Banjarmasin maka penulis menyarankan kepada pihak manajemen untuk melakukan kenaikan tarif angkutan sebesar $\mathrm{Rp} 25.000,00 / \mathrm{m}^{3}$.

2. Berkaitan dengan biaya langsung yang dikeluarkan perusahaan,penulis merasa sudah tidak ada ruang bagi perusahaan untuk melakukan efisiensi karena berkaitan dengan aturan pihak ketiga yakni pemerintah dan instansi terkait. Contoh, biaya perizinan, pajak, sertifikasi ABK, biaya perjalanan kapal dll. Semua ini sudah sesuai ketentuan yang ditetapkan pemerintah maka perusahaan harus mencari celah efisiensi di sector biaya lain yang dirasa memberatkan modal kerja perusahaan. Penulis menyoroti tentang pengambilan kredit investasi yang dilakukan perusahaan yang dirasa sangat sia sia karena terjadi pembengkakan biaya bunga yang mengakibatkan beban lain perusahaan menjadi besar.

3. PT Pelayaran Bina Benua Samudera juga membebankan biaya hiburan yang cenderung sia sia karena sama sekali tidak ada keterkaitan dengan usaha jasa pelayaran. Alangkah baiknya semua biaya hiburan di alokasikan perusahaan untuk membayari hutang jangka pendeknya yang nilainya sangat besar yakni Rp 76.496.811.004, pada tahun 2016.

4. Untuk memperbaiki cash ratio perusahaan diharapkan lebih ketat dalam pemberian piutang afiliasi kepada perusahaan lain karena apabila kas terkuras banyak untuk membiayai perusahaan lain ini bisa berakibat jeleknya rasio kinerja perusahaan utamanya cash ratio.

5. PT Pelayaran Bina Benua Samudera juga diharapkan tidak terlalu berani dalam berspekulasi ini bisa berakibat salah kebijakan. Di tengah kurang stabilnya ekonomi dunia perusahaan diharapkan hati hati dalam pengambilan kebijakan yang strategis. Contoh, pengambilan kredit investasi yang nilainya sangat besar pada bulan Mei 2016.

6. PT Pelayaran Bina Benua Samudera mencatatkan nilai minor pada sisi cash ratio di tahun 2016 yang mencatatkan nilai 14\% jauh dari data rata industri terkait yang mencapai 53\%. Hal ini di sebabkan nilai hutang lancar perusahaan terlalu besar yang nilainya $\mathrm{Rp}$ 76.496.811.004. Implikasi dari kurangnya alokasi dana untuk pembayaran hutang lancar perusahaan di mana perusahaan terlalu banyak mengalokasikan untuk pembelian aset yang yang nilainya $\operatorname{Rp} 35.203 .577 .280$, pada tahun 2016. Menurut penulis seandainya perusahaan 
mengalokasikan 20 milyar dari alokasi pembelian aset di alihkan untuk membayar hutang lancarnya akan memperbaiki nilai cash rationya.

\section{DAFTAR PUSTAKA}

Ambarwati Sri Dwi Ari, 2013, Modal Kerja Dalam Penguatan Income Afiliasi Perusahaan, Gramedia, Jakarta.

Kasmir, 2012, Analisis Laporan Keuangan, Rajawali Pers, Jakarta.

Munawir, 2013, Cara Mudah Memahami Angka dan Manajemen Keuangan Bagi Orang Awam, Gramedia, Jakarta.

Riyanto Bambang, 2012, Dasardasar Pembelanjaan, Edisi 4, BPFE, Yogyakarta. 